\title{
Trace metal uptake rates in crustaceans (amphipods and crabs) from coastal sites in NW Europe differentially enriched with trace metals
}

\author{
P. S. Rainbow ${ }^{1, *}$, C. Amiard-Triquet ${ }^{2}$, J. C. Amiard ${ }^{2}$, B. D. Smith ${ }^{1}$, S. L. Best ${ }^{3}$, \\ Y. Nassiri ${ }^{4}$, W. J. Langston ${ }^{5}$ \\ 'Dept of Zoology, The Natural History Museum, Cromwell Rd, London SW7 5BD, United Kingdom \\ ${ }^{2}$ Service d'Ecotoxicologie, CNRS-EP 61, ISOMer, Faculté de Pharmacie, 1 rue Gaston Veil, F-44035 Nantes Cedex 01, France \\ ${ }^{3}$ School of Biological Sciences, Queen Mary \& Westfield College, London E1 4NS, United Kingdom \\ ${ }^{4}$ Laboratoire de Biologie Marine, CNRS-EP 61, ISOMer, Faculté des Sciences et Techniques, \\ 2 rue de la Houssinière, BP 92208 , F-44322 Nantes Cedex 03, France \\ ${ }^{5}$ Plymouth Marine Laboratory, Citadel Hill, Plymouth PL1 2PB, United Kingdom
}

\begin{abstract}
This study set out to investigate the possible effect of life history strategy on the trace metal biology of crustaceans living in coastal sites contaminated by high availabilities of toxic metals. Amphipods brood their young, parents and offspring staying in the same habitat. Therefore a population of amphipods living in a trace-metal-rich estuary would have been selected over generations for any physiological adaptation reducing the potential toxic action of the trace metals, such as reduced rates of uptake of metals from solution. Crabs, on the other hand, are dispersed by a planktonic larval phase, the zoea, increasing the probability that the parents of individuals inhabiting a metal-rich estuary would have lived in a remote location not exposed to selection pressure to reduce metal uptake rates. Uptake rates of the dissolved trace metals $\mathrm{Zn}, \mathrm{Cd}$ and $\mathrm{Ag}$ were, therefore, measured in amphipods Orchestia gammarellus and crabs Carcinus maenas and Pachygrapsus marmoratus from coastal sites in Britain and France exposed to different degrees of trace metal enrichment, in order to test 3 hypotheses: (1) the mean metal uptake rates of amphipods and crabs from a metal-rich site would be lower than those of the same crustaceans from a control site; (2) the mean metal uptake rates of amphipods would show a greater reduction from those of control amphipods than would those of equivalent crabs; (3) the mean metal uptake rates of amphipods from metal-rich sites would show smaller coefficients of variation than those of equivalent crabs. In practice the mean metal uptake rates of both amphipods and crabs did not show consistent significant differences between the crustaceans from the metal-rich and control sites. Furthermore there was no evidence to conclude that the coefficients of variation of the mean uptake rates of amphipods from the relatively metal-rich sites are lower than those of crabs from the same sites. It is concluded that the exposure of the crustaceans to raised trace metal availabilities has not been sufficient to select for a reduction in dissolved trace metal uptake rates, even in the case of the in situ populations of amphipods. It is relevant that a suite of physiological mechanisms for the amelioration of the potential toxic effects of trace metals is available to coastal invertebrates, and it remains possible that other physiological processes promoting metal tolerance may be active to differing degrees in crustaceans from metal-rich habitats.
\end{abstract}

KEY WORDS: Trace metals - Uptake rates - Amphipods - Crabs · Orchestia gammarellus · Carcinus maenas Pachygrapsus marmoratus $\cdot$ Life history

\section{INTRODUCTION}

Estuarine and coastal invertebrates exposed to potentially toxic bioavailabilities of trace metals like $\mathrm{Zn}$

•E-mail: p.rainbow@nhm.ac.uk and $\mathrm{Cd}$ are under selective pressure to evolve physiological adaptations to reduce the potential of toxic action, both lethal and sublethal. In effect they are under selective pressure to evolve metal tolerance. Indeed Klerks \& Weis (1987) were able to conclude that many populations of aquatic organisms living in 
heavy-metal-polluted areas do have an increased resistance to the toxic effects of the metals. Moreover the presence of metal-tolerant populations of organisms in an estuary provides evidence that the metal contamination of that estuary is of ecotoxicological significance, particularly if that metal tolerance is heritable (Luoma 1977). For example, populations of the polychaete worm Nereis diversicolor from Restronguet Creek, a notorious metal-contaminated site in Cornwall, UK, are tolerant to both $\mathrm{Cu}$ and $\mathrm{Zn}$ (Bryan \& Hummerstone 1971, 1973b, Bryan \& Gibbs 1983, Grant et al. 1989, Hateley et al. 1989), as are crabs Carcinus maenas from this site (Bryan \& Gibbs 1983). Increased tolerance to $\mathrm{Cu}$ is also found in Restronguet Creek populations of nematode worms (Millward \& Grant 1995), the polychaete Nephtys hombergi, the bivalve mollusc Scrobicularia plana and the amphipod crustacean Corophium volutator (Bryan \& Gibbs 1983).

Organisms experience toxicity when the rate of entry of a toxin into the body exceeds the rate at which that toxin may be excreted and/or otherwise detoxified (rendered metabolically unavailable). This study examines one aspect of this equation-the rates of trace metal uptake from solution of crustaceans living in coastal sites differentially enriched with trace metals, investigating whether selective pressures have been sufficient to promote reductions in metal uptake rates. It also considers another aspect-that of the interaction of life history strategy and any such selection pressure. Populations of crustaceans living in toxic metalrich habitats might be expected to show different degrees of variability in a physiological process promoting metal tolerance (such as a reduced uptake rate of a dissolved trace metal), according to the nature of their life history. For example, a population of amphipod crustaceans which brood their young would be selected over generations, parents and offspring staying in the same habitat. Thus, natural selection might promote an optimum solution with consequent reduction in physiological variability. A metal-tolerant population of amphipods from a metal-contaminated estuary might, therefore, have a low dissolved metal uptake rate with a limited coefficient of variation (standard deviation to mean ratio). On the other hand if the crustacean population is dispersed via a planktonic larval stage (as in the case of crabs with zoeal larvae), then the parents of various members of that population might well have lived in many different locations, including distant habitats not exposed to selection pressure promoting metal tolerance. Thus, selection in the metal-contaminated site has acted on individuals with no family history of selection for metal tolerance. Crabs surviving in the metal-contaminated site may rely individually on any of a range of physiological adaptations for metal tolerance, of which a reduced rate of dissolved metal uptake is one possibility (see Mason \& Jenkins 1995). The mean metal uptake rate of such a metal-tolerant population might be lower than those of control populations, but would have a high coefficient of variation in comparison to the amphipod example discussed above.

This study therefore set out to measure dissolved trace metal uptake rates in populations of crabs and amphipods collected from coastal sites exposed to different degrees of trace metal enrichment, including control sites. The hypotheses to be tested state: (1) amphipods and crabs from metal-rich sites will have lower trace metal uptake rates than their counterparts from control sites; (2) the mean metal uptake rates of amphipods from the more metal-rich habitats will show a greater percentage reduction from control uptake rates; (3) the mean uptake rates of the amphipods from the relatively metal-rich sites will show a smaller coefficient of variation than will the mean uptake rates of crabs from these same sites.

The sites chosen as metal-rich are Restronguet Creek, Cornwall, and Dulas Bay, Anglesey, in the UK and the Gironde Estuary in France (Fig. 1). Restronguet Creek is a branch of the Fal Estuary System, which receives discharge from the Carnon River that drains the district of St Day, Redruth and Camborne, which has a long history of mining for metals such as $\mathrm{Cu}$, Sn and As (Dines 1969, Bryan \& Gibbs 1983). Despite cessation of active mining, the River Carnon and its estuary, Restronguet Creek, still contain extraordinarily high levels of $\mathrm{As}, \mathrm{Cd}, \mathrm{Cu}, \mathrm{Fe}, \mathrm{Mn}$ and $\mathrm{Zn}$ (Bryan \& Gibbs 1983, Bryan et al. 1987). Dulas Bay on the east coast of Anglesey in North Wales is fed by Afon Goch, an acid mine stream rising on Parys Mountain which was mined for $\mathrm{Cu}$ until the late nineteenth century (Foster et al. 1978). Afon Goch and therefore Dulas Bay have very high levels of $\mathrm{Cu}, \mathrm{Fe}, \mathrm{Mn}$ and $\mathrm{Zn}$ (Foster 1976, Foster et al. 1978, Boult et al. 1994). Oysters Crassostrea gigas from the Gironde contain elevated concentrations of $\mathrm{Cd}, \mathrm{Cu}$ and $\mathrm{Zn}$, as shown by biomonitoring from 1979 to 1993 (RNO 1995), and they are also high in Ag (Amiard-Triquet unpubl.) compared to other sites (Martoja et al, 1988, Berthet et al. 1990, Métayer et al. 1990).

The control sites are Millport in the Firth of Clyde, Scotland, and Talmont St Hilaire, Vendée, near Les Sables d'Olonne on the Atlantic coast of France (Fig. 1).

The crustaceans studied are the amphipod Orchestia gammarellus (Pallas), and the crabs Carcinus maenas (L.) and Pachygrapsus marmoratus (Fabricius), the choice being made on the basis of their distribution and the availability of techniques to measure their rates of trace metal uptake.

The terms 'uptake' and 'accumulation' are often used carelessly as synonyms. Here, uptake refers to the flux of all metal entering the body of the crustacean (in these 


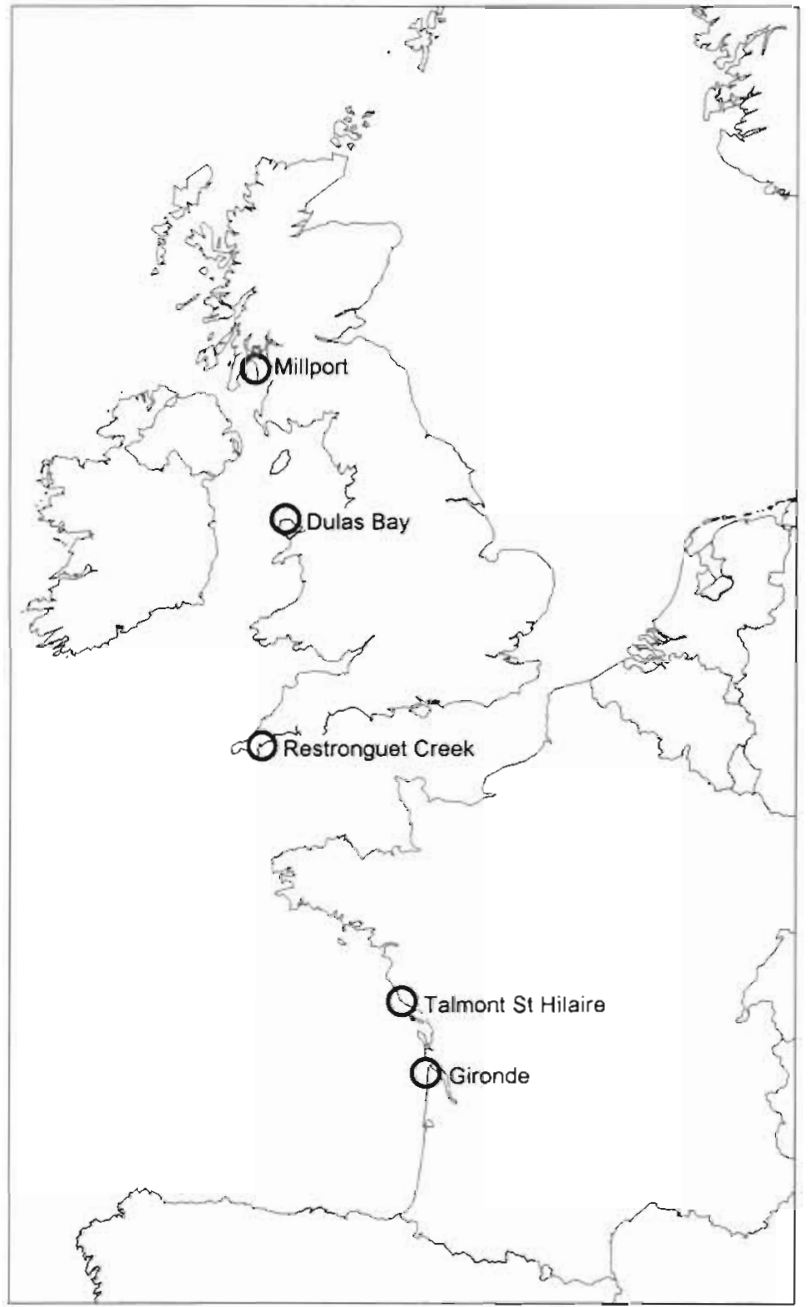

Fig. 1. Sites at which crustaceans were collected in 1996 and 1997. Metal-rich sites: Restronguet Creek, Dulas Bay, Gironde; control sites: Millport, Talmont St Hilaire

experiments, always from solution and always of radioactively labelled metal). Accumulation, on the other hand, is equivalent to net uptake or net flux, that is absolute uptake minus excretion. If excretion is occurring, then clearly accumulation is not synonymous with uptake. If, however, there is no excretion of metal in the time period of the experiment, then accumulation is directly equivalent to uptake, and is indeed then a measure of uptake. This was the case in our experiments.

Techniques have been well established for the measurement of the rates of uptake of $\mathrm{Zn}$ and $\mathrm{Cd}$ from solution by Orchestia gammarellus, using sequential live counting of amphipods exposed to radioactively labelled metal tracers; there is no excretion of radiolabelled metal accumulated from solution over the short time period used in the experiments and the rate of accumulation of this labelled metal in this short term is a direct measure of the rate of metal uptake from solu- tion (Rainbow \& White 1989, Weeks \& Rainbow 1991, Rainbow et al. 1993, Rainbow \& Kwan 1995). For example, Weeks \& Rainbow (1991) exposed O. gammarellus to a series of radiolabelled $\mathrm{Zn}$ concentrations for $21 \mathrm{~d}$ at $10^{\circ} \mathrm{C}$, and showed that at all exposures the labelled $\mathrm{Zn}$ concentration newly accumulated by the amphipods matched the increases in total $\mathrm{Zn}$ concentration. The conclusion drawn is that all $\mathrm{Zn}$ taken up from solution in this period (in contrast to $\mathrm{Zn}$ assimilated from food; Weeks \& Rainbow 1990, 1994) is retained as accumulated Zn without excretion, a conclusion supported by the confirmation of the absence of labelled $\mathrm{Zn}$ in the urine of amphipods exposed to dissolved Zn (Weeks \& Rainbow 1991). The beachhopper O. gammarellus is also available at all sites chosen.

Chan \& Rainbow (1993a,b) have shown that labelled Zn taken up from solution (as opposed to food) by the shore crab Carcinus maenas is accumulated without excretion within the time scales used here (except at very high $\mathrm{Zn}$ concentrations above those used here). All radiolabelled $\mathrm{Zn}$ taken up from solution by crabs exposed to radiolabelled dissolved $Z n$ concentrations up to $100 \mu \mathrm{g} \mathrm{l}^{-1}$ was added sequentially to the $\mathrm{Zn}$ concentration already present in the crabs (Chan \& Rainbow 1993a), and this accumulated $\mathrm{Zn}$ is not excreted (Chan \& Rainbow 1993b). Measures of rates of whole body net accumulation of radiolabelled $\mathrm{Zn}$ therefore also provide measures of absolute rates of $\mathrm{Zn}$ uptake from solution. Published literature on $\mathrm{Cd}$ accumulation by crustaceans (Jennings \& Rainbow 1979, Bjerregaard 1982, Rainbow 1985, 1988, 1998, Rainbow \& White 1989) indicates that the rate of accumulation of Cd by the crab will similarly reflect the rate of $\mathrm{Cd}$ uptake. Other (albeit relative) measures of the uptake rates of $\mathrm{Zn}$ and $\mathrm{Cd}$ from solution by C. maenas are provided by features of the accumulation kinetics of either metal in the haemolymph of the crab (Chan et al. 1992, Martin \& Rainbow 1998). Established techniques are thus available to measure trace metal uptake rates in this crab. Moreover C. maenas is distributed down the Atlantic coast of France as well as on British coasts.

The final crustacean chosen was the crab Pachygrapsus marmoratus. Although Carcinus maenas is present in France, P. marmoratus is often more common intertidally, and was included in the choice in order to ensure representation of crabs in collections from the Gironde. Nevertheless, both crab species were collected at each French site, providing a further test of the hypotheses proposed above.

\section{MATERIALS AND METHODS}

The crustaceans Orchestia gammarellus and Carcinus maenas were collected intertidally from Restronguet 
Creek (close to the Pandora Inn; 50 $12^{\prime} \mathrm{N}, 05^{\circ} 03^{\prime} \mathrm{W}$ ) and from Dulas Bay $\left(53^{\circ} 22^{\prime} \mathrm{N}, 04^{\circ} 17^{\prime} \mathrm{W}\right)$. Control amphipods and crabs from the shore $\left(55^{\circ} 44^{\prime} \mathrm{N}, 04^{\circ} 54^{\prime} \mathrm{W}\right)$ and immediate sublittoral near Millport (Isle of Cumbrae, Firth of Clyde) were supplied by the University Marine Biological Station, Millport. O. gammarellus, C. maenas and Pachygrapsus marmoratus were collected from the south shore of the Gironde Estuary, O. gammarellus at Le Phare de Richard $\left(45^{\circ} 22^{\prime} \mathrm{N}\right.$, $00^{\circ} 55^{\prime} \mathrm{W}$ ) and the crabs at Le Verdon-La Chambrette $\left(45^{\circ} 32^{\prime} \mathrm{N}, 01^{\circ} 03^{\prime} \mathrm{W}\right)$, near La Pointe de Grave. All 3 crustaceans were collected from the control shore at Talmont St Hilaire, Vendée $\left(46^{\circ} 24^{\prime} \mathrm{N}, 01^{\circ} 33^{\prime} \mathrm{W}\right)$. Samples of the macrophytic brown seaweed Fucus vesiculosus, the bladder wrack, were also taken from each collection site for biomonitoring purposes. Dates of collection are detailed in Tables 1 to 4 , and sites shown in Fig 1 .

Crustaceans were returned in cool boxes to the laboratory within a day (usually within hours) of collection and maintained at $10^{\circ} \mathrm{C}(12: 12 \mathrm{~h}$ light:dark) at Queen Mary \& Westfield College, London. The amphipods were kept in acid-washed covered plastic tanks with cast-up seaweed from the strandline of the site of collection on gravel wetted with seawater. The crabs were held in aerated laboratory seawater. Crustaceans collected from the Gironde in June 1997 were held in similar conditions for $2 \mathrm{wk}$ at about $15^{\circ} \mathrm{C}$ in Nantes, before transfer in cool boxes to London and subsequent maintenance at $10^{\circ} \mathrm{C}$. (The choice of a single experimental temperature, in this case $10^{\circ} \mathrm{C}$, was necessary to enable comparisons to be made between sites, and did require at least 1 set of experimental animals to be held at a temperature rarely met in the field.) For at least $4 \mathrm{~d}$ before uptake studies, experimental animals were maintained aerated in the artificial seawater TMN (Tropic Marin Neu, Tropicarium Buchshlag, Dreieich, Germany) to be used in all experiments (see below).

Subsamples of Orchestia gammarellus and Fucus vesiculosus were also frozen immediately for metal analysis to provide biomonitoring data ssee Bryan \& Gibbs 1983, Bryan et al. 1985, Rainbow et al. 1989, Moore et al. 1991). They were later dried to constant weight at $60^{\circ} \mathrm{C}$ and digested in concentrated nitric acid (Aristar grade, $\mathrm{BDH}$ ) at $100^{\circ} \mathrm{C}$. Each digest was made up to a known volume with double distilled water and analysed for trace metal content by atomic absorption spectrophotometry (AAS) on an IL-157 spectrophotometer with background correction as appropriate. The standard reference material Tort-1 (Lobster Hepatopancreas, NRC, Canada) was included in analyses. Details are given in Table 1 .

All metal concentrations are quoted in terms of dry weight unless otherwise stated.
Amphipod uptake experiments. Experiments were carried out at $10^{\circ} \mathrm{C}$ in fully aerated artificial seawater (TMN) at $33 \%$, ensuring reproducibility of physicochemical conditions that might affect trace metal uptake rates (Rainbow 1995a, 1997). Groups of $10 \mathrm{am}$ phipods of both sexes and of similar size (usually $>10 \mathrm{mg}$ dry wt) and moult stage (intermoult) were held individually in acid-washed perforated plastic containers (Toby 'Teaboys', Aldridge Plastics, Aldridge, UK). Typically experiments were carried out in $1 \mathrm{I}$ acidwashed plastic tanks with at least 2 replicates of each treatment, each tank containing up to 5 individually housed amphipods. In no case was there a statistically significant difference between replicates of treatments, so replicate data have all been grouped. Data for any amphipods moulting or dying were excluded from data analysis, thereby explaining variations in numbers between experiments. All experimental equipment was presoaked in experimental media including radiotracers to offset adsorption effects (Rainbow et al. 1993).

Measurement of uptake rates essentially followed the technique of Weeks \& Rainbow (1991), Rainbow et al. (1993) and Rainbow \& Kwan (1995). Amphipods exposed to radioactively labelled dissolved trace metal were counted live (on an LKB Wallac Compugamma model 1282) at daily intervals for $4 \mathrm{~d}$, giving a measure of 'new' labelled metal accumulated, itself a measure of absolute uptake from solution (see Rainbow \& White 1989, Weeks \& Rainbow 1991). Accumulation was linear and best-fit linear regression lines were fitted to data for individual amphipods for Days 1 to 4 , the zero point being excluded to allow for adsorption of labelled metal onto the exoskeleton (see Fig. 2). The few individual regressions that were not significant were excluded. Such (albeit infrequent) lack of a significant fit of a data set to a straight line may have been caused by technical errors of measurement, or might well be attributable to a real change in uptake rate by the amphipod during the experiment caused for example by a change of stage of the moult cycle. Regression coefficients (ng $\mathrm{g}^{-1} \mathrm{~d}^{-1}$ ), representing the metal uptake rates of individual amphipods, were grouped for further statistical analysis by ANOVA (Sokal \& Rohlf 1981).

Amphipods were exposed to 1 or more of the trace metals $\mathrm{Zn}$, Cd and $\mathrm{Ag}$, using the radioisotopes ${ }^{65} \mathrm{Zn}$, ${ }^{109} \mathrm{Cd}$ and ${ }^{110 \mathrm{M}} \mathrm{Ag}$ (NEN Life Science Products, Boston, USA) added to stock solutions of the respective metal chloride (Analar grade, BDH) to give experimental exposures of $100 \mu \mathrm{g} \mathrm{l}^{-1}$ with $5 \mathrm{\mu Ci}^{-1}$ tracer in TMN. Allowance was made as appropriate for any carrier metal in the radioisotopes supplied. $\mathrm{Zn}$ was chosen because this metal is present in high quantity at all 3 metal-rich sites with possible ecotoxicological consequences (see 'Introduction'), and ${ }^{65} \mathrm{Zn}$ is a convenient radiotracer. Cu appears also to be of ecological 
significance at the 3 sites but unfortunately lacks a suitable radioactive tracer for use here. $\mathrm{Cd}$, on the other hand, can be represented by the radioisotope ${ }^{109} \mathrm{Cd}$. Moreover $\mathrm{Cd}$ is present in atypically high levels in both Restronguet Creek and the Gironde. Comparisons of separate and simultaneous exposures of amphipods to raised concentrations of $\mathrm{Zn}$ and $\mathrm{Cd}$ were made in order to provide information on possible competition between the metals for uptake sites, though detailed analysis of these data will be considered in a future publication. Ag may be of ecotoxicological significance in the Gironde Estuary and is therefore a suitable metal with which to test the proposed hypotheses.

Details of amphipod uptake experiments are given in Table 2 .

Crab uptake experiments. Uptake into blood: Larger specimens (>44 mm carapace width) of Carcinus maenas, when available, were used to monitor the haemolymph concentrations of labelled $\mathrm{Zn}$ and $\mathrm{Cd}$ in exposed crabs. Following the technique of Martin \& Rainbow (1998), up to 10 crabs were exposed to

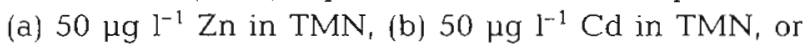
(c) $50 \mathrm{\mu g} \mathrm{l}^{-1} \mathrm{Zn}$ and $50 \mu \mathrm{g} \mathrm{l}^{-1} \mathrm{Cd}$ in TMN simultaneously, at $10^{\circ} \mathrm{C}$ for $4 \mathrm{~d}$ in individual acid-washed plastic containers which had been presoaked in the experimental medium. $\mathrm{Zn}$ and $\mathrm{Cd}$ solutions were labelled with $5 \mu \mathrm{Ci} \mathrm{l}^{-1}{ }^{65} \mathrm{Zn}$ and ${ }^{109} \mathrm{Cd}$ as appropriate. Haemolymph samples were taken each day and counted (LKB Wallac Compugamma) for labelled metal concentration. The labelled $\mathrm{Zn}$ concentration in the haemolymph continues to increase over the exposure period (see Fig. 3a). The rate of this increase (the regression coefficient of the best-fit line, expressed as $n g \mathrm{ml}^{-1} \mathrm{~d}^{-1}$ ) is directly proportional to the concentration of available $\mathrm{Zn}$ in the exposure solution (and hence the rate of Zn uptake into the crab-see Chan \& Rainbow 1993a,b), and can therefore be considered to be a surrogate (relative) measure of the crab's uptake rate of dissolved metal (Martin \& Rainbow 1998). The labelled $\mathrm{Cd}$ concentration in the haemolymph, on the other hand, rapidly reaches an equilibrium (see Fig. 3b) as its rate of removal from the haemolymph (to the hepatopancreas) matches its rate of uptake into the haemolymph (in the gills) under constant exposure (Martin \& Rainbow 1998). The equilibrium concentration of $\mathrm{Cd}$ in the haemolymph ( $\mathrm{ng} \mathrm{m}^{-1}$ ) does, however, increase with increased concentration of available $\mathrm{Cd}$ in solution, and therefore with the rate of cadmium uptake from solution into the whole crab. The equilibrium $\mathrm{Cd}$ concentration in the haemolymph therefore provides a surrogate relative measure of the rate of uptake of $\mathrm{Cd}$ from solution by the whole crab (Martin \& Rainbow 1998). Table 3 provides details of separate experiments.
Whole crab accumulation: Pachygrapsus marmoratus and smaller specimens of Carcinus maenas were used in experiments in which the accumulated concentrations of labelled $\mathrm{Zn}$ and $\mathrm{Cd}$ were measured in the whole crabs (see Chan \& Rainbow 1993a,b). As explained in the 'Introduction', the rates of (net) accumulation of $\mathrm{Zn}$ and $\mathrm{Cd}$ during these short-term experiments are considered to be direct measures of the absolute rates of uptake of $\mathrm{Zn}$ and $\mathrm{Cd}$ from solution by the whole crabs.

In 1996 Carcinus maenas from Restronguet Creek $(n=26)$, Dulas Bay $(n=24)$ and Millport $(n=27)$, and Pachygrapsus marmoratus from the Gironde $(n=20)$ and Talmont St Hilaire $(n=20)$, were exposed for $11 \mathrm{~d}$ at $10^{\circ} \mathrm{C}$ to $50 \mu \mathrm{g} \mathrm{l}^{-1} \mathrm{Zn}$ and $50 \mathrm{\mu g} \mathrm{l}^{-1} \mathrm{Cd}$ (labelled with $5 \mu \mathrm{Ci} \mathrm{l}^{-1}{ }^{65} \mathrm{Zn}$ and $5 \mu \mathrm{Ci} \mathrm{l}{ }^{-1}{ }^{109} \mathrm{Cd}$ ) together in TMN in presoaked acid-washed plastic containers. C. maenas were held in groups of 3 (1 crab from each site) per container, and $P$. marmoratus in pairs (1 from each site). Up to 5 C. maenas and $4 P$. marmoratus were sampled on Days 1, 2, 4 and 7, and all remaining crabs on Day 11, to be frozen prior to analysis. Specimens were subsequently thawed, dried to constant weight at $60^{\circ} \mathrm{C}$, acid digested (to provide a homogenous solution and thereby avoid geometric effects on counting), and counted for labelled $\mathrm{Zn}_{\mathrm{n}}$ and $\mathrm{Cd}$ contents. Data for any crab that moulted during the experiment were ignored.

In 1997 Carcinus maenas from Restronguet Creek ( $\mathrm{n}=10)$, Millport $(\mathrm{n}=4)$, Gironde $(\mathrm{n}=9)$ and Talmont ( $\mathrm{n}=10$ ), and Pachygrapsus marmoratus from Gironde ( $\mathrm{n}=11$ ) were similarly exposed for $21 \mathrm{~d}$. C. maenas were held in groups of 3 or 4 ( 1 crab from each site), and $P$. marmoratus in pairs. Crabs were sampled on Days 7,14 and 21, before being dried, acid digested and counted as above.

Statistical analysis. All statistical analyses, including regression analysis and ANOVA, were carried out using STATISTICA (Statsoft).

\section{RESULTS}

\section{Biomonitoring}

Table 1 gives the concentrations of trace metals in Orchestia gammarellus and Fucus vesiculosus from the sites investigated, the results for the standard reference material confirming the acceptability of the analyses. Zn concentrations were not elevated in amphipods from any of the sites, but relatively high concentrations of $\mathrm{Zn}$ were found in the bladder wrack from Dulas Bay, Restronguet Creek and the Gironde. $\mathrm{Cu}$ concentrations were raised in both amphipods and seaweed from Dulas Bay and Restronguet Creek. No O. gammarellus from any site had elevated Cd concen- 
Table 1. Concentrations $\left(\mu \mathrm{g} \mathrm{g}^{-1}\right.$ ) of trace metals in Orchestia gammarellus (concentration with $95 \%$ confidence limits in $0.01 \mathrm{~g}$ dry wt amphipod as estimated from double log regressions of concentration against dry weight in order to allow for size effects [Rainbow et al. 1989], $\mathrm{n}=10$ ) and Fucus vesiculosus (mean $+1 \mathrm{SD}, \mathrm{n}=6$ except for Gironde where $\mathrm{n}=3$ ) from 5 coastal sites (date of collection). Gironde A: Le Phare de Richard; Gironde B: Le Verdon-La Chambrette. Also shown are metal concentrations (mean $\pm 1 \mathrm{SE}, \mathrm{n}=3$ ) measured in Tort-1 standard reference material, certified values being quoted with $95 \%$ tolerance limits (TL). nd: not determined

\begin{tabular}{|c|c|c|c|c|}
\hline & $\mathrm{Zn}$ & $\mathrm{Cu}$ & $\mathrm{Cd}$ & $\mathrm{Ag}$ \\
\hline \multicolumn{5}{|l|}{ Orchestia gammarellus } \\
\hline Millport (26 Jun 1997) & $186(127,271)$ & $63.8(46.4,87.9)$ & $12.7(5.7,28.4)$ & nd \\
\hline Dulas Bay (23 Sep 1997) & $126(107,149)$ & $105(82.9,133)$ & $9.1(7.6,10.9)$ & nd \\
\hline Restronguet Creek (25 Jun 1997) & $169(143,195)$ & $136(99.1,185)$ & $9.8(7.4,13.0)$ & nd \\
\hline Gironde A (23 Jun 1997) & $152(103,224)$ & $59.3(49.8,70.5)$ & $11.4(8.8,14.7)$ & nd \\
\hline Talmont (4 Jul 1997) & $123(112,136)$ & $54.2(45.1,65.1)$ & $12.3(8.4,18.1)$ & nd \\
\hline \multicolumn{5}{|l|}{ Fucus vesiculosus } \\
\hline Millport (27 Jun 1997) & $23.3 \pm 5.5$ & $1.42 \pm 0.56$ & $0.97 \pm 0.32$ & $0.39 \pm 0.13$ \\
\hline Dulas Bay (23 Sep 1997) & $283 \pm 115$ & $246 \pm 106$ & $1.39 \pm 0.35$ & $0.51 \pm 0.14$ \\
\hline Restronguet Creek (25 Jun 1997) & $199 \pm 124$ & $93.3 \pm 25.5$ & $0.99 \pm 0.23$ & $0.35 \pm 0.13$ \\
\hline Gironde A (1 Nov 1995) & $175 \pm 10$ & $18.5 \pm 0.8$ & $7.68 \pm 0.07$ & $3.18 \pm 0.18$ \\
\hline Gironde B (1 Nov 1995) & $156 \pm 5.0$ & $18.8 \pm 1.0$ & $4.55 \pm 0.07$ & $2.99 \pm 0.02$ \\
\hline Talmont (4 Jul 1997) & $43.1 \pm 16.5$ & $6.80 \pm 2.79$ & $1.91 \pm 0.72$ & $1.03 \pm 0.49$ \\
\hline \multicolumn{5}{|l|}{ Tort-1 standard reference material } \\
\hline Measured mean $\pm \mathrm{SE}$ & $165 \pm 36.7$ & $406 \pm 81.5$ & $27.0 \pm 2.4$ & $1.16 \pm 0.38$ \\
\hline Certified value $\pm 95 \% \mathrm{TL}$ & $177 \pm 10$ & $439 \pm 22$ & $26.3 \pm 2.1$ & - \\
\hline
\end{tabular}
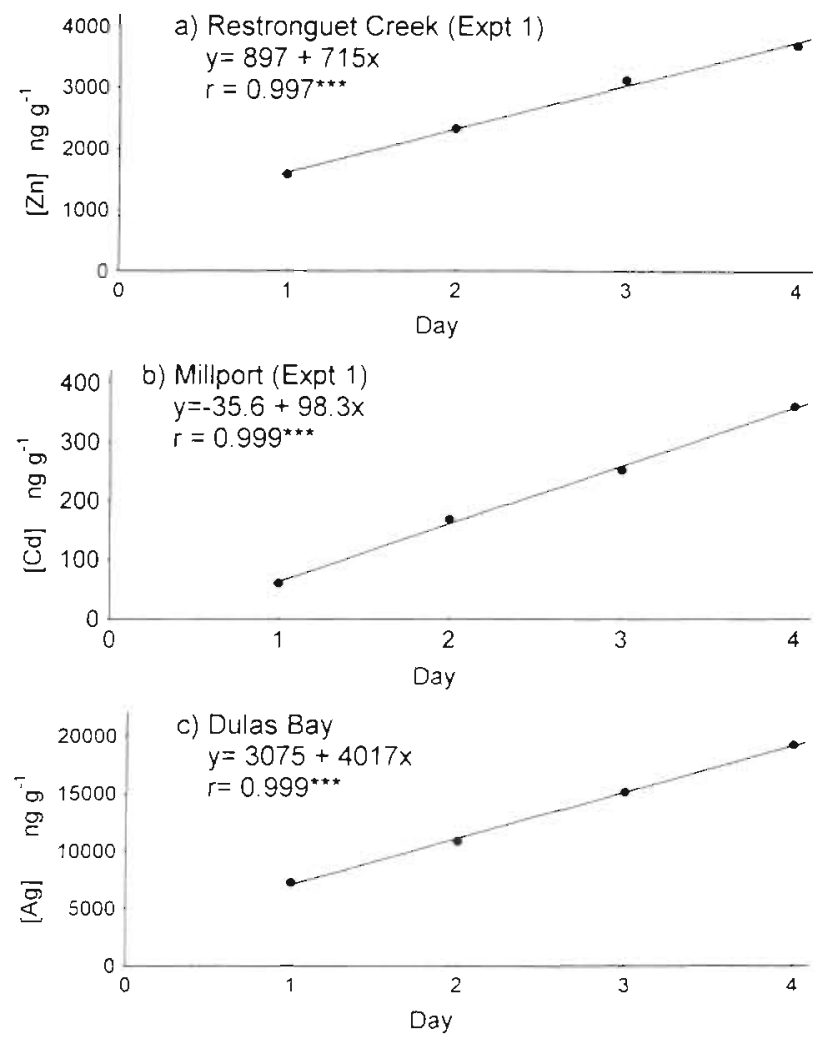

Fig. 2. Orchestia gammarellus. Typical patterns of the linear accumulation of radioactively labelled (a) $\mathrm{Zn}$, (b) $\mathrm{Cd}$ and (c) Ag by individual amphipods exposed to $100 \mu \mathrm{gl}^{-1}$ labelled $\mathrm{Zn}, \mathrm{Cd}$ or $\mathrm{Ag}$ at $10^{\circ} \mathrm{C}$. In each case the slope of the best fit regression line $(\cdots p<0.001)$ is a measure of the rate of uptake $\left(\mathrm{ng} \mathrm{g}^{-1} \mathrm{~d}^{-1}\right.$ ) of the metal by the amphipod trations, though $\mathrm{Cd}$ concentrations in $\mathrm{F}$. vesiculosus from the Gironde sites were higher than elsewhere. Ag concentrations in $F$. vesiculosus from the Gironde were also atypically high.

\section{Amphipod uptake rates}

Fig. 2 shows typical patterns of the short-term accumulation of labelled $\mathrm{Zn}, \mathrm{Cd}$ and $\mathrm{Ag}$ by Orchestia gammarellus, the slope of the regression line of best fit representing the uptake rate of an individual amphipod. Table 2 gives the mean uptake rates of $\mathrm{Zn}, \mathrm{Cd}$ and $\mathrm{Ag}$ by the amphipods in the separate experiments, and the results of ANOVA comparisons of these uptake rates within and between experiments as appropriate.

Zinc uptake. The only significant $(p<0.05)$ intersite difference between $\mathrm{Zn}$ uptake rates (Table 2) was between amphipods from Dulas Bay and Millport (Expt 2; $F_{\mathrm{s}}=6.49 ; 1,12 \mathrm{df}_{;} \mathrm{p}=0.026$ ), with Orchestia gammarellus from Dulas Bay showing a reduced uptake rate $(54 \%$ of that of the control site). There were no significant differences between uptake rates of amphipods from all the other sites, whether or not in the presence of raised $\mathrm{Cd}$ availability (Table 2). Interestingly, the significant difference in Zn uptake rates between Dulas Bay and Millport amphipods did not occur in the presence of $100 \mu \mathrm{g} \mathrm{Cd} \mathrm{^{-1 }}$

In order to assess whether it was possible to compare uptake rates for amphipods from different sites if measured in different experiments, a comparison was 
Table 2. Orchestia gammarellus. Mean uptake rates ( $\mathrm{ng} \mathrm{g}^{-1} \mathrm{~d}^{-1}$ ) with SD of labelled $\mathrm{Zn}$, Cd or Ag in amphipods from 5 sites (dates of collection) exposed to labelled (a) $100 \mu \mathrm{g} \mathrm{l}^{-1} \mathrm{Zn}$, (b) $100 \mu \mathrm{g} \mathrm{l}^{-1} \mathrm{Cd}$, (c) $100 \mu \mathrm{g} \mathrm{l}^{-1} \mathrm{Zn}$ and $100 \mu \mathrm{g} \mathrm{l}^{-1} \mathrm{Cd}$ together, or (d) $100 \mu \mathrm{gg} \mathrm{l}^{-1} \mathrm{Ag}$ at $10^{\circ} \mathrm{C}$. Coefficient of variation (CV) is SD/mean. $\bullet$ CV not included in Table 5 data set - see 'Discussion' ANOVA Site: metal uptake rates of amphipods from different sites sharing the same letter in the same treatment in one experiment do not differ significantly ( $\mathrm{p}>0.05$ ). ANOVA Time: metal uptake rates of amphipods from the same site subjected to the same treatment in different experiments sharing the same letter do not differ significantly $(p>0.05)$. Where letter codes are not presented for amphipods from a site subjected to the same treatment in different experiments, metal uptake rates did not differ significantly between experiments

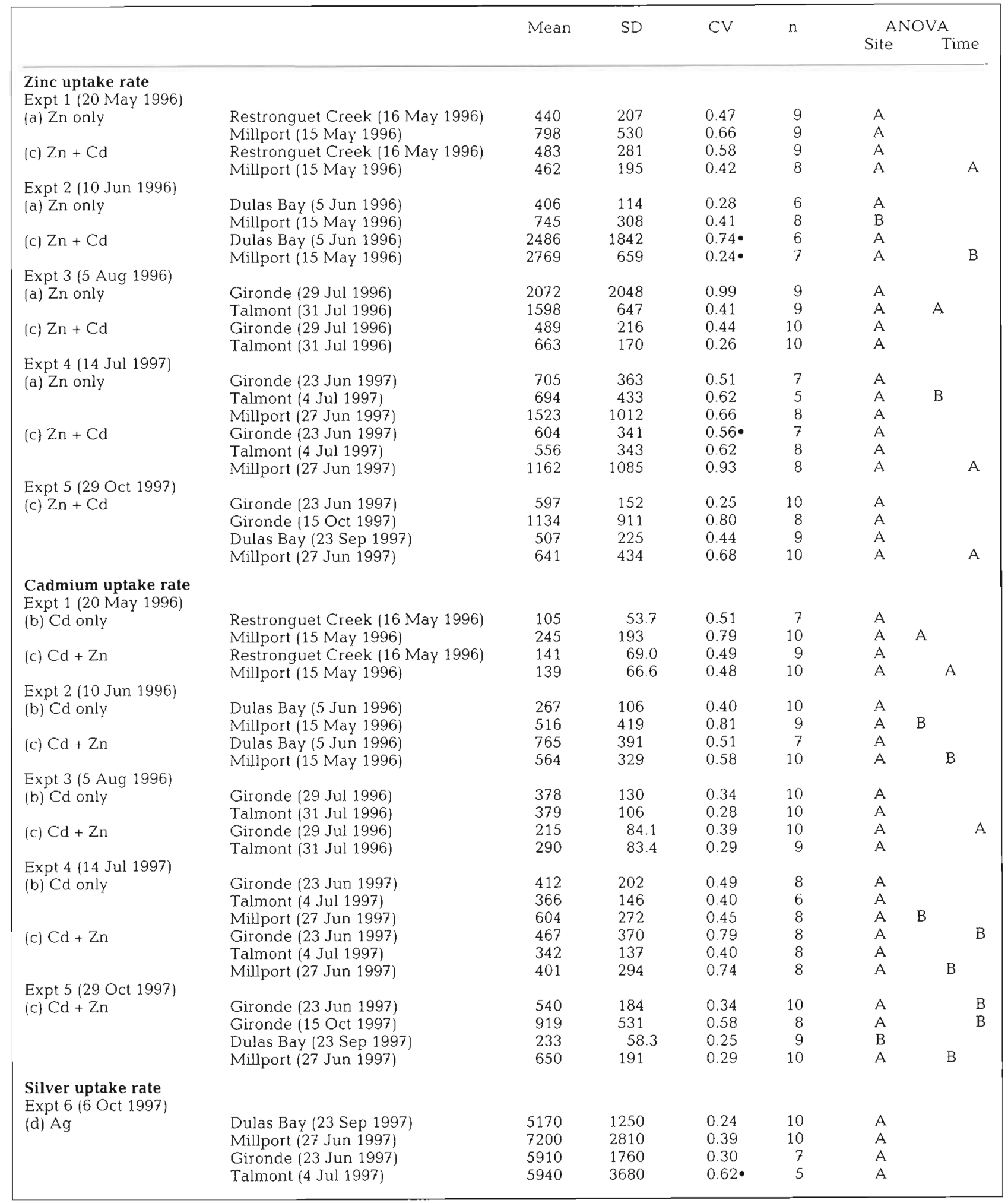


made between $\mathrm{Zn}$ uptake rates of amphipods from single sites at different times (Table 2). These time comparisons did, however, show up significant differences within a site (e.g. Talmont 1996 vs 1997 in absence of high Cd, Millport June 1996 vs the other dates in the presence of high $\mathrm{Cd}$ ). It was decided therefore not to compare $\mathrm{Zn}$ uptake rates in amphipods from different sites measured in different experiments.

Cadmium uptake. There were no significant differences in $\mathrm{Cd}$ uptake rates of amphipods from the different sites in the experiments carried out in the absence of raised $\mathrm{Zn}$ (Table 2 ). There was a single significantly different $\mathrm{Cd}$ uptake rate apparent when amphipods were exposed to the $\mathrm{Cd}$ in the additional presence of $100 \mathrm{\mu g} \mathrm{l}^{-1}$ of $\mathrm{Zn}$ (Table 2). The Dulas Bay amphipods collected in 1997 had a significantly lowered Cd uptake rate from those from the Gironde and Millport (Expt 5; $\left.F_{\mathrm{s}}=8.63 ; 3,33 \mathrm{df} ; \mathrm{p}=0.000\right)$, an effect not detected in Expt 2 in 1996 (Table 2). Given the variability of these results, it cannot be concluded that the Dulas Bay amphipods show reduced Cd uptake.

Comparisons of $\mathrm{Cd}$ uptake rates of amphipods from the same site but measured in different experiments showed up significant differences in uptake rates of Millport amphipods over time (May 1996 amphipods [Expt 1] having low rates), but not for Gironde or Talmont ones (Table 2). In the presence of raised $\mathrm{Zn}$, $\mathrm{Cd}$ uptake rates of Millport amphipods again varied over time with May 1996 ones, again having a low uptake rate (Table 2). The Cd uptake rate of Gironde amphipods in high $\mathrm{Zn}$ also varied significantly over time, with August 1996 amphipods (Expt 3) showing a significantly lowered rate.

Silver uptake. There were no significant differences between the Ag uptake rates of amphipods from Dulas Bay, Millport, Gironde and Talmont (Table 2).

Amphipod metal uptake rates. In summary therefore, with the possible exception of the lower $\mathrm{Zn}$ uptake rate of Dulas Bay amphipods, it is not possible to conclude that amphipods from the more metal-rich sites have lower trace metal uptake rates than those from control sites.

\section{Crab uptake rates}

As measured from blood parameters

Fig. 3 shows typical patterns of the short-term accumulation of labelled $\mathrm{Zn}$ and $\mathrm{Cd}$ in the blood of the shore crab Carcinus maenas exposed in the laboratory. As explained in the 'Materials and methods', the slope

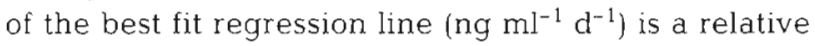
measure of the uptake rate of dissolved $\mathrm{Zn}$ by the crabs, whereas in the case of $\mathrm{Cd}$ it is the plateau equi-
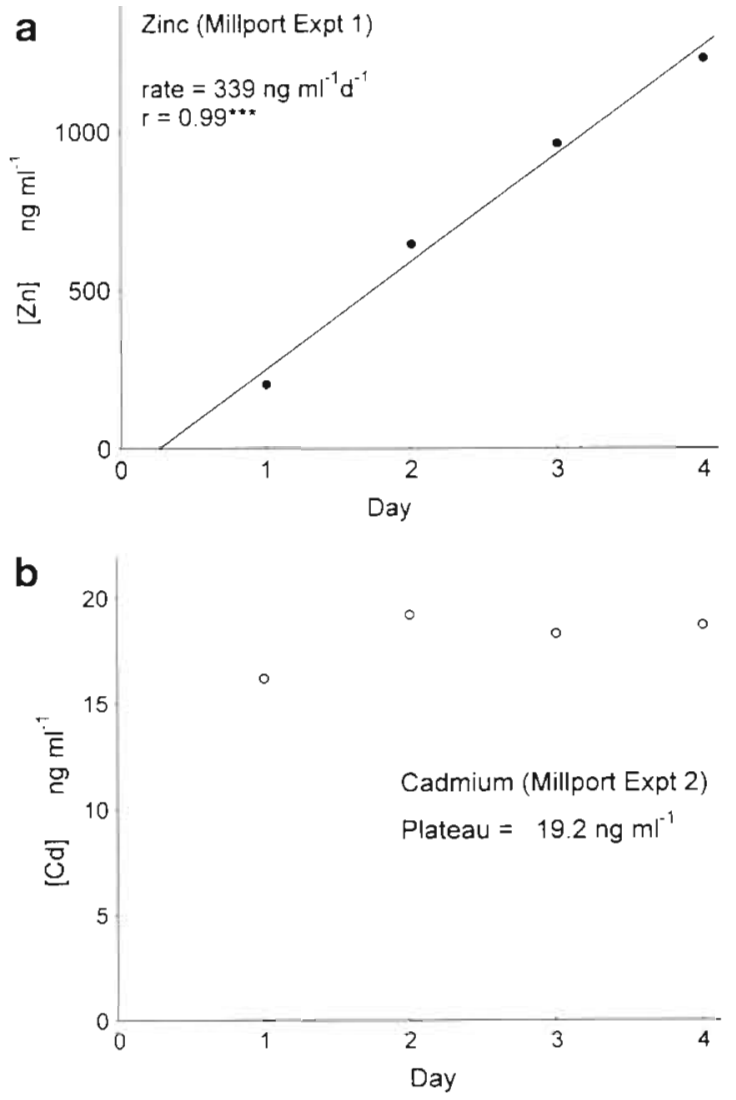

Fig. 3. Carcinus maenas. Typical patterns of the accumulation of labelled (a) $\mathrm{Zn}(\cdots \mathrm{p}<0.001)$ and (b) Cd in the blood of crabs exposed to $50 \mu \mathrm{gl}^{-1} \mathrm{Zn}$ or $\mathrm{Cd}$ at $10^{\circ} \mathrm{C}$

librium concentration of $\mathrm{Cd}$ in the blood $\left(\mathrm{ng} \mathrm{Cd} \mathrm{m}{ }^{-1}\right.$ ) that is the relative measure of the rate of dissolved $\mathrm{Cd}$ uptake by the crabs. Table 3 summarises the data obtained and provides ANOVA comparisons.

Zinc uptake. Two significant site differences were apparent in the case of rates of $\mathrm{Zn}$ uptake by the crab Carcinus maenas (Table 3 ). The rate of $\mathrm{Zn}$ uptake by crabs from Dulas Bay was significantly raised above that of Millport crabs in June 1996 (Expt 2; $F_{\mathrm{s}}=53.8$; $1,15 \mathrm{df}_{i} \mathrm{p}=0.000$ ), as was the rate of $\mathrm{Zn}$ uptake of Talmont crabs above those of Restronguet Creek, Millport and Gironde in July 1997 (Expt $4_{i} F_{\mathrm{s}}=3.30$; $3,21 \mathrm{df}_{\mathrm{i}} \mathrm{p}=0.040$ ). No crabs showed intrasite differences in $\mathrm{Zn}$ uptake rates over time (Table 3).

Cadmium uptake. A single intersite significant difference was identified for rates of Cd uptake (Table 3). As for Zn uptake, Dulas Bay crabs also had a significantly raised rate of $\mathrm{Cd}$ uptake in comparison to Millport crabs in June 1996 (Expt $2 ; F_{\mathrm{s}}=151 ; 1,15 \mathrm{df}$; $p=0.000$ ). In the case of $C d$, there were significant differences in $\mathrm{Cd}$ uptake rate over time for Millport crabs, the June 1996 crabs differing significantly in Cd uptake rate from the July 1997 ones (Table 3) 
Table 3. Carcinus maenas. Mean relative uptake rates with $\mathrm{SD}$ of labelled $\mathrm{Zn}\left(\mathrm{ng} \mathrm{m} \mathrm{m}^{-1} \mathrm{~d}^{-1}\right.$ in haemolymph) and $\mathrm{Cd}$ (ng $\mathrm{ml} \mathrm{l}^{-1}$ in haemolymph) of crabs from 5 sites (dates of collection) exposed to labelled (a) $50 \mu \mathrm{g} \mathrm{l}^{-1} \mathrm{Zn}$, (b) $50 \mu \mathrm{gl}^{-1} \mathrm{Cd}$, or (c) $50 \mu \mathrm{g} \mathrm{l^{-1 }} \mathrm{Zn}$ and $50 \mu \mathrm{g} \mathrm{l}^{-1} \mathrm{Cd}$ together at $10^{\circ} \mathrm{C}$. Coefficient of variation (CV) is SD/mean. $\bullet$ : CV not included in Table 5 data set-see 'Discussion'. ANOVA Site, Time: details given in Table 2

\begin{tabular}{|c|c|c|c|c|c|c|c|}
\hline & & \multirow[t]{2}{*}{ Mean } & \multirow[t]{2}{*}{ SD } & \multirow[t]{2}{*}{$\mathrm{CV}$} & \multirow[t]{2}{*}{ n } & \multicolumn{2}{|c|}{ ANOVA } \\
\hline & & & & & & Site & Time \\
\hline \multicolumn{8}{|l|}{ Zinc uptake rate } \\
\hline \multicolumn{8}{|l|}{ Expt 1 (20 May 1996) } \\
\hline (a) Zn only & Millport (15 May 1996) & 57.3 & 42.8 & 0.75 & 6 & & \\
\hline \multirow[t]{2}{*}{ (c) $\mathrm{Zn}+\mathrm{Cd}$} & Restronguet Creek (16 May 1996) & 68.7 & 44.2 & 0.64 & 8 & A & \\
\hline & Millport (15 May 1996) & 45.1 & 19.5 & 0.43 & 9 & A & \\
\hline \multicolumn{8}{|l|}{ Expt 2 (10 Jun 1996) } \\
\hline \multirow{2}{*}{ (c) $\mathrm{Zn}+\mathrm{Cd}$} & Dulas Bay (5 Jun 1996) & 234 & 72.9 & 0.31 & 8 & A & \\
\hline & Millport (15 May 1996) & 49.1 & 19.5 & $0.40 \bullet$ & 9 & B & \\
\hline \multicolumn{8}{|l|}{$\begin{array}{l}\text { Expt } 3 \text { (5 Aug 1996) } \\
\text { (c) Zn+ Cd }\end{array}$} \\
\hline (c) $\mathrm{Zn}+\mathrm{Cd}$ & Gironde (29 Jul 1996) & 81.4 & 72.1 & 0.89 & 6 & A & \\
\hline & Talmont (31 Jul 1996) & 104 & 53.7 & 0.52 & 8 & A & \\
\hline \multicolumn{8}{|l|}{ Expt 4 (14 Jul 1997) } \\
\hline \multirow[t]{4}{*}{ (c) $\mathrm{Zn}+\mathrm{Cd}$} & Restronguet Creek (25 Jun 1997) & 50.7 & 25.1 & 0.49 & 6 & A & \\
\hline & Millport (27 Jun 1997) & 75.0 & 35.0 & 0.47 & 7 & A & \\
\hline & Gironde (23 Jun 1997) & 91.1 & 79.3 & 0.87 & 6 & A & \\
\hline & Talmont (4 Jul 1997) & 203 & 163 & 0.80 & 6 & $B$ & \\
\hline \multicolumn{8}{|l|}{ Cadmium uptake rate } \\
\hline \multicolumn{8}{|l|}{ Expt 1 (20 May 1996) } \\
\hline (b) Cd only & Millport (15 May 1996) & 17.6 & 9.1 & $0.52 \bullet$ & 7 & & \\
\hline \multirow[t]{2}{*}{ (c) $\mathrm{Cd}+\mathrm{Zn}$} & Restronguet Creek (16 May 1996) & 18.8 & 15.0 & 0.80 & 8 & A & \\
\hline & Millport (15 May 1996) & 18.0 & 10.0 & 0.56 & 9 & A & $A, B$ \\
\hline \multicolumn{8}{|l|}{ Expt 2 (10 Jun 1996) } \\
\hline \multirow[t]{2}{*}{ (c) $\mathrm{Cd}+\mathrm{Zn}$} & Dulas Bay (5 Jun 1996) & 76.1 & 13.2 & 0.17 & 8 & A & \\
\hline & Millport (15 May 1996) & 15.5 & 6.5 & 0.42 & 9 & B & A \\
\hline \multirow{3}{*}{$\begin{array}{l}\text { Expt } 3 \text { (5 Aug 1996) } \\
\text { (c) Cd + Zn }\end{array}$} & & & & & & & \\
\hline & Gironde (29 Jul 1996) & 17.2 & 12.5 & 0.73 & 6 & A & \\
\hline & Talmont (31 Jul 1996) & 26.2 & 19.8 & 0.76 & 7 & A & \\
\hline \multirow{5}{*}{$\begin{array}{l}\text { Expt } 4(14 \text { Jul 1997) } \\
\quad \text { (c) Cd + Zn }\end{array}$} & & & & & & & \\
\hline & Restronguet Creek (25 Jun 1997) & 19.8 & 14.9 & 0.75 & 6 & A & \\
\hline & Millport (27 Jun 1997) & 30.5 & 14.7 & 0.48 & 7 & A & $\mathrm{B}$ \\
\hline & Gironde (23 Jun 1997) & 28.5 & 18.7 & 0.66 & 6 & A & \\
\hline & Talmont (4 Jul 1997) & 45.4 & 22.1 & $0.49 \bullet$ & 6 & A & \\
\hline
\end{tabular}

Crab metal uptake rates. As for the amphipods, therefore, it is not possible to conclude that crabs from the more metal-rich sites have lower trace metal uptake rates than those from control sites.

\section{As measured by whole crab accumulation rates}

Zinc and cadmium accumulation. Fig, 4 shows a typical accumulation pattern, in this case of Cd by 1996 Millport crabs. Details of all rates of accumulation are given in Table 4 .

The rates of accumulation of $\mathrm{Zn}$ by the whole crabs (Table 4) did not differ significantly between Carcinus maenas from Millport, Dulas Bay and Restronguet Creek in 1996, nor did the rates of Cd accumulation (Table 4). Similarly the rate of $\mathrm{Zn}$ or $\mathrm{Cd}$ accumulation by whole C. maenas did not differ between crabs from Millport, Restronguet Creek, Gironde and Talmont in 1997. There was also no significant difference in rates of $\mathrm{Zn}$ or $\mathrm{Cd}$ accumulation by the whole crabs between Pachygrapsus marmoratus from Gironde and Talmont (Table 4).

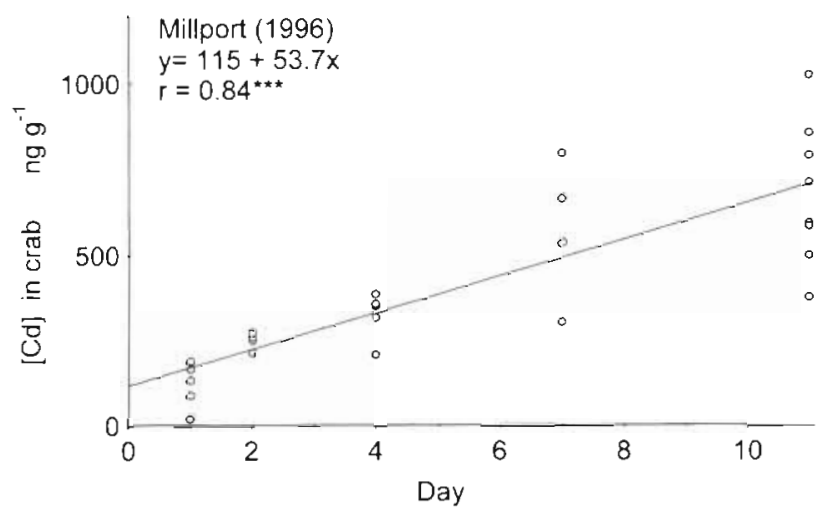

Fig. 4. Carcinus maenas. The accumulation of labelled $\mathrm{Cd}$ by whole crabs (summated totals) after exposure to $50 \mu \mathrm{g}^{-1}$ labelled $\mathrm{Cd}$ for up to $11 \mathrm{~d}$ at $10^{\circ} \mathrm{C}$, as reported in Table 4 (Millport 1996). Each point represents an individual crab.

$$
(\cdots p<0.001)
$$

Thus, as for metal uptake rates of crabs measured from parameters of the accumulation of trace metals in the blood, it cannot be concluded that crabs from the more metal-rich sites have lower whole body metal uptake rates than those from control sites. 
Table 4. Rates of accumulation $\left(\mathrm{ng} \mathrm{g}^{-1} \mathrm{~d}^{-1}\right)$ with SE of labelled $\mathrm{Zn}$ and Cd in crabs (Carcinus maenas and Pachygrapsus marmoratus) from 5 sites (see Table 3 for collection details, $P$. marmoratus being collected on the same day as C. maenas from the named site) when exposed to labelled $50 \mu \mathrm{g} \mathrm{l}^{-1} \mathrm{Zn}$ and $50 \mu \mathrm{g} \mathrm{l}^{-1} \mathrm{Cd}$ together for 11 (1996) or $21 \mathrm{~d}(1997)$ at $10^{\circ} \mathrm{C}$. ANOVA Site, Time: details given in Table 2. ANOVA Species: metal accumulation rates of crabs of different species subjected to the same treatment in the same experiments sharing the same letter do not differ significantly ( $p>0.05$ )

\begin{tabular}{|c|c|c|c|c|c|c|}
\hline & \multirow[t]{2}{*}{ Mean } & \multirow[t]{2}{*}{ SE } & \multirow[t]{2}{*}{$\mathrm{n}$} & \multicolumn{3}{|c|}{ ANOVA } \\
\hline & & & & Site & Time & Species \\
\hline \multicolumn{7}{|l|}{ Zinc accumulation rate } \\
\hline \multirow{2}{*}{\multicolumn{7}{|c|}{$\begin{array}{l}\text { Carcinus maenas } \\
1996\end{array}$}} \\
\hline & & & & & & \\
\hline Millport & 46.1 & 16.2 & 27 & A & \multirow[t]{2}{*}{ A } & \\
\hline Dulas Bay & 111 & 26.7 & 24 & A & & \\
\hline Restronguet Creek & 85.2 & 29.5 & 26 & A & A & \\
\hline \multicolumn{7}{|l|}{1997} \\
\hline Millport & 92.8 & 143 & 4 & A & A & \multirow{4}{*}{ A } \\
\hline Restronguet Creek & 509 & 162 & 10 & A & A & \\
\hline Gironde & 465 & 221 & 9 & A & & \\
\hline Talmont & 625 & 233 & 9 & A & & \\
\hline \multirow{2}{*}{\multicolumn{7}{|c|}{ Pachygrapsus marmoratus }} \\
\hline & & & & & & \\
\hline Gironde & 563 & 161 & 18 & A & \multicolumn{2}{|c|}{ A } \\
\hline Talmont & 204 & 86.0 & 20 & A & & \\
\hline \multicolumn{7}{|l|}{1997} \\
\hline Gironde & 104 & 98.6 & 10 & & A & A \\
\hline \multirow{2}{*}{\multicolumn{7}{|c|}{$\begin{array}{l}\text { Cadmium accumulation rate } \\
\text { Carcinus maenas } \\
1096\end{array}$}} \\
\hline & & & & & & \\
\hline 1996 & & & & & & \\
\hline Millport & 53.7 & 7.9 & 27 & A & \multirow[t]{2}{*}{ A } & \\
\hline Dulas Bay & 97.0 & 67.0 & 24 & A & & \\
\hline Restronguet Creek & 95.6 & 22.7 & 26 & A & A & \\
\hline \multicolumn{7}{|l|}{1997} \\
\hline Millport & 0.0 & 29.3 & 4 & A & \multirow{2}{*}{$A^{A}$} & \multirow{4}{*}{ A } \\
\hline Restronguet Creek & 47.8 & 14.3 & 10 & A & & \\
\hline Gironde & 95.1 & 11.5 & 9 & A & & \\
\hline Talmont & 133 & 168 & 9 & A & & \\
\hline \multicolumn{7}{|c|}{$\begin{array}{l}\text { Pachygrapsus marmoratus } \\
1996\end{array}$} \\
\hline Gironde & 206 & 50.8 & 18 & A & \multicolumn{2}{|c|}{ A. } \\
\hline Talmont & 86.8 & 28.6 & 20 & A & & \\
\hline \multicolumn{7}{|l|}{1997} \\
\hline Gironde & 76.2 & 16.1 & 10 & & A & A \\
\hline
\end{tabular}

Accumulation rates of $\mathrm{Zn}$ and $\mathrm{Cd}$ by crabs from the same site but in the 2 years 1996 and 1997 were compared by ANOVA (Table 4). There were no significant differences between years in either $\mathrm{Zn}$ or $\mathrm{Cd}$ accumulation rates of Carcinus maenas from both Restronguet Creek and Millport. Similarly, in the case of Pachygrapsus marmoratus from the Gironde, neither the rate of accumulation of $\mathrm{Zn}$ nor that of Cd differed between 1996 and 1997 (Table 4).

It is also possible to make an interspecific comparison between the accumulation rates of $\mathrm{Zn}$ and $\mathrm{Cd}$ of Carcinus maenas and Pachygrapsus marmoratus. Neither the rate of accumulation of $\mathrm{Zn}$ nor that of $\mathrm{Cd}$ differed significantly between $C$. maenas (1997) and P. marmoratus (1997) from the Gironde (Table 4). There are therefore no interspecific differences in the accumulation rates (and hence absolute uptake rates) of $\mathrm{Zn}$ and $\mathrm{Cd}$ between the 2 crab species.

\section{Comparison of coefficients of variation}

One of the hypotheses under test states that the amphipods from metal-rich habitats will have mean uptake rates with a smaller coefficient of variation (CV) than will crabs from these habitats. The CV is the ratio of the SD to the mean. Both standard deviation and mean of a sample are independent of the number of replicates in that sample after a minimum replicate number has been taken. Thus the calculated $\mathrm{CV}$ will not change significantly with further increase in the number of replicates in the sample.

It is necessary therefore to ask whether the CVs reported here (e.g. Tables $2 \& 3$ ) have been calculated using a sufficient number of replicates - i.e.
Fig. 5. Coefficients of variation (CVs). Typical graphs showing changes in mean ( \pm 1 SD) and $\mathrm{CV}$ with the sequential addition of individuals in the sample (in this case of the Cd uptake rate of the sample of 9 Orchestia gammarellus exposed to $\mathrm{Zn}$ and $\mathrm{Cd}$ in Expt 1 of Table 2), plotted in order to verify whether estimates of CVs in Tables $2 \& 3$ are acceptable (see 'Results: Comparison of coefficients of variation')

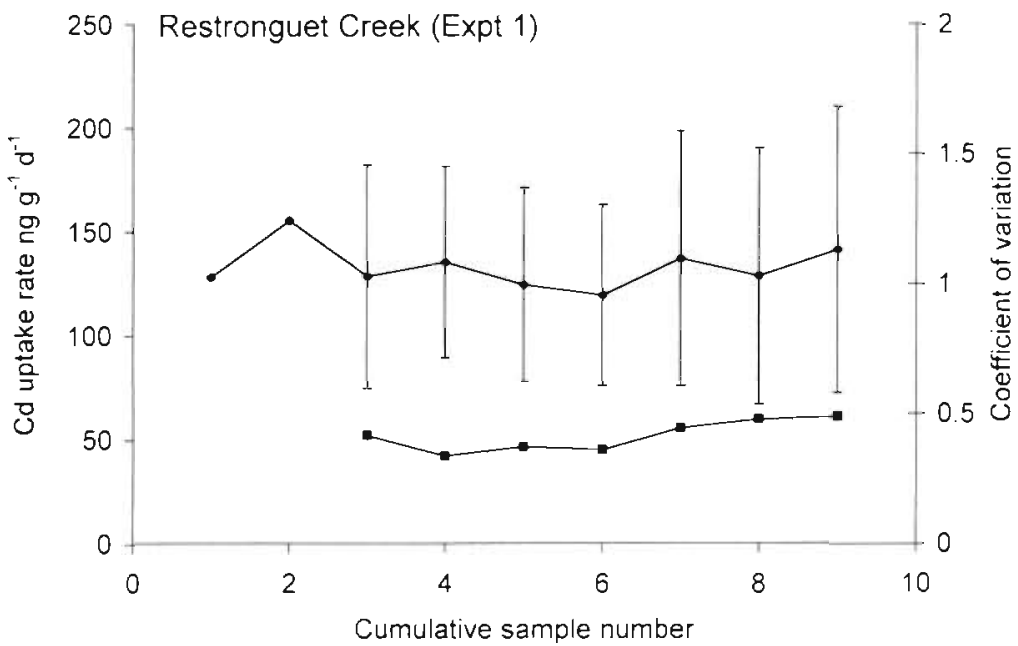


the calculated value would not have changed if more replicates had been taken. Insight into this question can be gained by plotting the mean uptake rate against the sequential number of replicates in an experiment, as illustrated in Fig. 5. This figure shows the mean Cd uptake rate (with SD) and the CV of the sample of 9 Orchestia gammarellus from Restronguet

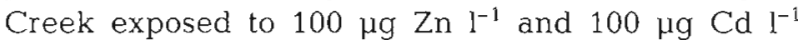
simultaneously (Expt 1, Table 2). The calculated mean rate of uptake, $\mathrm{SD}$ and $\mathrm{CV}$ all appear to stabilise quickly. It can be concluded therefore that 9 replicates were more than sufficient in this case to establish the mean, SD and therefore CV with confidence.

A repeat procedure for each data set summarised in Table 2 confirmed that sufficient replicates had been taken in all but 4 cases (identified in the table). The remaining coefficients reported in Table 2 can therefore be used for further analyses (see Table 5). Similar procedures were carried out for all crab data sets (Table 3), and all but 3 data sets for $Z n$ and Cd relative uptake rates were acceptable for further analysis.

An intersite comparison by ANOVA of the CVs of the mean metal uptake rates of Orchestia gammarellus (Table 5) showed no significant difference across all sites. There was, however, a significant intersite difference between CVs of the mean relative metal uptake rates of Carcinus maenas $\left(F_{\mathrm{s}}=7.52 ; 4,14 \mathrm{df} ; \mathrm{p}=0.002\right)$ (Table 5). There was no significant difference across these CVs for Restronguet Creek, Gironde and Talmont crabs, the coefficients for Dulas Bay and Millport crabs being lower.

The hypothesis under test requires the CVs of the mean metal uptake rates of the amphipods from the metal-rich sites to be lower than those of the mean relative metal uptake rates of crabs from the same sites. This in fact was not the case for Dulas Bay or Restronguet Creek (Table 5). On the other hand, it was

Table 5. Coefficients of variation of mean uptake rates of $\mathrm{Zn}$, $\mathrm{Cd}$ and $\mathrm{Ag}$ by the amphipod Orchestia gammarellus (from Table 2) and the crab Carcinus maenas (from Table 3) from different sites

\begin{tabular}{|lcrr|}
\hline & Mean & Range & $\mathrm{n}$ \\
\hline Amphipods: uptake rates (O. gammarellus) & \\
Dulas Bay & 0.35 & $0.24-0.51$ & 6 \\
Restronguet Creek & 0.51 & $0.47-0.58$ & 4 \\
Gironde & 0.52 & $0.25-0.99$ & 12 \\
Millport & 0.59 & $0.29-0.93$ & 14 \\
Talmont & 0.41 & $0.29-0.62$ & 8 \\
Crabs: uptake rates (C. maenas) & & & \\
Dulas Bay & 0.24 & $0.17-0.31$ & 2 \\
Restronguet Creek & 0.67 & $0.49-0.80$ & 4 \\
Gironde & 0.79 & $0.66-0.89$ & 4 \\
Millport & 0.52 & $0.42-0.75$ & 6 \\
Talmont & 0.69 & $0.52-0.80$ & 3 \\
& & & \\
\hline
\end{tabular}

true for the Gironde $\left(F_{\mathrm{s}}=4.88 ; 1,14 \mathrm{df} ; \mathrm{p}=0.044\right)$, and also for the control site of Talmont $\left(F_{\mathrm{s}}=8.38\right.$; $1,9 \mathrm{df}_{\mathrm{i}} \mathrm{p}=0.018$ ). There was no significant difference between CVs of the mean metal uptake rates of amphipods and crabs from Millport (Table 5).

Given the lack of predicted differences for Dulas Bay and Restronguet Creek samples, it is not possible to conclude that the CVs of the mean uptake rates of amphipods from relatively metal-rich sites are lower than those of crabs from these sites.

\section{DISCUSSION}

A first point to be confirmed is whether the sites chosen represent a range of trace metal availabilities from metal-rich to control. The biomonitoring data presented in Table 1 provide the evidence. Table 6 lists comparative biomonitoring data available in the literature.

In the case of $\mathrm{Zn}$, a body concentration in Orchestia gammarellus above $200 \mu \mathrm{g} \mathrm{g}^{-1}$ indicates a high local Zn availability (Table 6, Rainbow et al. 1989, Moore et al. 1991). Coincidentally the same approximate concentration can be considered as the upper limit in samples of the bladder wrack Fucus vesiculosus not affected by $\mathrm{Zn}$ contamination (Table 6). Of the bladder wrack samples collected in this study, $F$. vesiculosus from Dulas Bay, Restronguet Creek (just) and the Gironde (possibly) confirm the presence of high ambient $\mathrm{Zn}$ availabilities. The collection site for the Restronguet Creek samples in this study (the first site at which amphipods and crabs were found in sufficient abundance for experiments) is towards the seaward end of the Creek. It is to be expected therefore that the $\mathrm{Zn}$ concentrations in $O$. gammarellus would be lower than those in amphipods collected in low numbers further upstream by Rainbow et al. (1989) and Weeks (1992) (Table 6). Similarly, it is understandable that the $\mathrm{Zn}$ concentrations in our samples of bladder wrack are lower than those of Bryan \& Gibbs (1983) (Table 6) collected further upstream in Restronguet Creek. Surprisingly, at first sight, our seaweed sample has a lower $\mathrm{Zn}$ concentration than that reported by Bryan \& Gibbs (1983) for F. vesiculosus from Weir Point, downstream of the mouth of the Creek (Table 6). This may be a consequence of the particular portion of the wrack analysed (Bryan \& Hummerstone 1973a), but probably results from the variation over time of metal loads entering the Creek from the Carnon River. Trace metal loads in the Carnon River and Restronguet Creek have in fact slowly declined since mine closure in 1991, with the exception of a flooding event in 1992 (Langston unpubl.). Nonetheless it is clear that $\mathrm{Zn}$ bioavailabilities are relatively high at the sites in Dulas Bay and 
Table 6. Comparative biomonitoring data ( $\mu \mathrm{g} \mathrm{g}^{-1}$ dry wt) for $\mathrm{Zn}, \mathrm{Cu}, \mathrm{Cd}$ and $\mathrm{Ag}$ in (a) Orchestia gammarellus (mean conc. or conc. in $0.01 \mathrm{~g}$ dry wt amphipod as in Table 1) and (b) Fucus vesiculosus (mean conc.) in NW Europe. Sources: (a) Weeks (1992), (b) Rainbow et al. (1989), (c) Moore et al. 1991, (d) Bryan \& Hummerstone (1973a), (e) Bryan \& Gibbs (1983), (f) Foster (1976), (g) Fuge \& James (1974), (h) Bartlett \& Ashcroft (1985)

\begin{tabular}{|c|c|c|c|c|c|}
\hline & Zn & $\mathrm{Cu}$ & $\mathrm{Cd}$ & $\mathrm{Ag}$ & Source \\
\hline \multicolumn{6}{|l|}{ (a) Orchestia gammarellus } \\
\hline Restronguet Creek (mean) & 274 & 362 & & & a \\
\hline Restronguet Creek $(0.01 \mathrm{~g})$ & 392 & 139 & & & $\mathrm{~b}$ \\
\hline N. Queensferry (0.01 g) & $252-340$ & $76.1-130$ & & & c \\
\hline Tamar, Weir Key (mean) & 181 & 177 & & & a \\
\hline Tamar, Torpoint $(0.01 \mathrm{~g})$ & 212 & 120 & & & $\mathrm{~b}$ \\
\hline St Andrews $(0.01 \mathrm{~g})$ & 168 & 145 & & & c \\
\hline Whithorn, Scotland $(0.01 \mathrm{~g})$ & 173 & 129 & 1.4 & & $\mathrm{~b}$ \\
\hline Dulas Bay (mean) & 151 & 117 & & & a \\
\hline Hayle, Cornwall (mean) & 126 & 90.3 & & & a \\
\hline Millport, Scotland (mean) & 192 & 86.6 & & & a \\
\hline Millport, Scotland $(0.01 \mathrm{~g})$ & $152-188$ & $63.4-92.0$ & 1.6 & & $\mathrm{~b}$ \\
\hline Millport, Scotland $(0.01 \mathrm{~g})$ & $123-227$ & $49.3-80.6$ & & & $\mathrm{c}$ \\
\hline Kilve, Somerset $(0.01 \mathrm{~g})$ & 167 & 74.9 & 7.4 & & $\mathrm{~b}$ \\
\hline Powfoot, Scotland $(0.01 \mathrm{~g})$ & 120 & 76.2 & & & $\mathrm{~b}$ \\
\hline Girvan, Scotland $(0.01 \mathrm{~g})$ & 152 & 66.0 & & & b \\
\hline Loch Indaal $(0.01 \mathrm{~g})$ & 122 & 61.3 & & & $\mathrm{~b}$ \\
\hline \multicolumn{6}{|l|}{ (b) Fucus vesiculosus } \\
\hline Restronguet Creek & 1240 & 301 & & & d \\
\hline Restronguet Creek & $2440-4200$ & $717-1450$ & $0.81-1.41$ & $0.60-2.21$ & $21 \mathrm{e}$ \\
\hline R. Creek, Weir Point & 2190 & 190 & 0.93 & 0.31 & e \\
\hline Dulas Bay & 306 & 71 & & & f \\
\hline Tamar & 262 & 68 & & & d \\
\hline Tamar & 113 & 27 & 0.81 & 0.24 & e \\
\hline Hayle & 1864 & 436 & 2.27 & 0.81 & e \\
\hline Camel & 149 & 17 & & & $\mathrm{~d}$ \\
\hline Dart & 199 & 9 & & & $\mathrm{~d}$ \\
\hline Looe & 104 & 8 & 1.39 & 0.37 & $\mathrm{e}$ \\
\hline Bristol Channel & $88-262$ & $3.8-14.3$ & $3.8-19.5$ & & g \\
\hline Humber Estuary & $405-725$ & $29.1-71$ & $2.3-8.2$ & & $\mathrm{~h}$ \\
\hline Lincolnshire coast & 133 & 14.4 & 1.13 & & $\mathrm{~h}$ \\
\hline
\end{tabular}

the $\mathrm{Cu}$ concentrations in our samples of $F$. vesiculosus from Restronguet Creek are expectedly lower than those reported from further upstream in Restronguet Creek by Bryan \& Gibbs (1983), and again lower than those from Weir Point prior to the cessation of active mining (Bryan \& Gibbs 1983). Nevertheless, as for $\mathrm{Zn}, \mathrm{Cu}$ bioavailabilities are confirmed to be high at the sites of collection in Dulas Bay and Restronguet Creek.

Fewer comparative data are available for $\mathrm{Cd}$ (Table 6 ). In the absence of reference data for $\mathrm{Cd}$ concentrations in Orchestia gammarellus, Rainbow et al. (1989) considered amphipods from Kilve on the Bristol Channel to have a high body concentration $17.4 \mu \mathrm{g} \mathrm{Cd}$ $\left.\mathrm{g}^{-1}\right)$. The higher body concentrations (9.1 to $12.7 \mathrm{\mu g} \mathrm{Cd} \mathrm{g}^{-1}$ ) reported here (Table 1), however, are similar across all the sites, and probably therefore represent typical background concentrations. Cd concentrations measured in Fucus vesiculosus in this study (Table 1) are similarly typical of noncontaminated sites (Table 6), with the probable exception of the sites in the Gironde. As observed by Bryan \& Gibbs (1983), the high dissolved concentrations of $\mathrm{Cd}$ in Restronguet Creek are not translated into high

(still) Restronguet Creek from which the current samples were collected.

Cu concentrations in our samples of Orchestia gammarellus from Dulas Bay and Restronguet Creek fall close to the top of their reported ranges (Rainbow et al. 1989, Moore et al, 1991), reflecting the high local Cu availabilities at these sites compared with Millport, Gironde and Talmont. Cu concentrations reported here for amphipods from Restronguet Creek and Dulas Bay (Table 1) agree well with those of Rainbow et al. (1989) for the former site and Weeks (1992) for the latter (Table 6). The higher Cu concentrations (Table 6) in the Restronguet Creek amphipods of Weeks (1992) again reflect their site of collection (further upstream than in this study), and the higher ambient trace metal bioavailabilities present during the period of active mining. The evidence from amphipod data of high $\mathrm{Cu}$ availabilities in Dulas Bay and Restronguet Creek is supported by the data for Fucus vesiculosus. The $\mathrm{Cu}$ concentrations in bladder wrack from these 2 sites (Table 1) are also high and above levels expected from non-contaminated sites (Table 6). As in the case of $\mathrm{Zn}$, accumulated concentrations in the local aquatic fauna and flora, probably as a result of competition for uptake sites by the extremely high ambient availability of dissolved $\mathrm{Zn}$. This is a classic example of a situation where the physicochemical measurement of a dissolved metal concentration (in this case $\mathrm{Cd}$ ) does not represent a measurement of its local bioavailability, confirming the value of biomonitors in providing integrated measures of the local availabilities of metals of ecological significance (Rainbow 1995b).

The concentrations of Ag measured in the samples of bladder wrack (Table 1) when compared against literature values (Table 6) suggest that atypically high Ag availability was present only in the Gironde.

Given, therefore, that the sites chosen represent a range of bioavailabilities of $\mathrm{Zn}$ and $\mathrm{Cu}$ (and to a lesser extent Ag) from high to low, it is now possible to address the 3 hypotheses proposed above. The first hypothesis predicts a reduced rate of uptake of metal (in this case $\mathrm{Zn}$ ) in both amphipods and crabs from sites with high $\mathrm{Zn}_{n}$ availability, represented here by Dulas Bay and Restronguet Creek. Although amphi- 
pods from Dulas Bay did have lower $\mathrm{Zn}$ uptake rates than those from Millport in one experiment, this result was not repeated in the presence of a high $\mathrm{Cd}$ concentration nor were there corroborative results from other site comparisons. Since there were also differences in the measured $\mathrm{Zn}$ uptake rates of amphipods from the same site between experiments, it is not possible to conclude generally that amphipods from sites with high $\mathrm{Zn}$ availability have a reduced rate of $\mathrm{Zn}$ uptake. It cannot be ruled out, however, that the collection of samples from sites closer to the metal source in Restronguet Creek, Dulas Bay and even the Gironde may have produced crustaceans with the predicted uptake rates, but this did not prove to be pragmatically possible.

With the possible exception of the Gironde, none of the sites proved to have high $\mathrm{Cd}$ availability, although it remained possible that a reduced rate of $\mathrm{Zn}$ uptake might be reflected in a reduced rate of $\mathrm{Cd}$ uptake, given the similarity between the chemistries of these 2 trace metals (Nieboer \& Richardson 1980). In fact the sample of Dulas Bay amphipods with the low $\mathrm{Zn}$ uptake rate (Expt 2, Table 2) did not have a significantly reduced $\mathrm{Cd}$ uptake rate, although a later sample from Dulas Bay (Expt 5, Table 2) did. The lack of consistency in these results again prevents the conclusion that amphipods from sites with high $\mathrm{Zn}_{\mathrm{n}}$ and $\mathrm{Cu}$ availabilities have a reduced uptake rate of another trace metal, in this case Cd. Similarly, there was no evidence for a reduced rate of uptake of $\mathrm{Ag}$ on the part of amphipods from such sites.

Crab data also fail to support the first hypothesis No crabs from the sites identified as metal-rich had reduced rates of either $\mathrm{Zn}$ or Cd uptake, however measured. Indeed Carcinus maenas from Dulas Bay had raised uptake rates of both metals, and the rate of $\mathrm{Zn}$ uptake of crabs from the control site Talmont was also raised in one comparative experiment (Expt 4) but not the other (Expt 3, Table 3). Both $\mathrm{Zn}$ and Cd uptake rates of the Dulas Bay crabs (Table 3 ) were atypically high. When the Dulas Bay crabs were collected in June 1996, many of the crabs at the site were moulting. It is possible therefore that the Dulas Bay crabs used in the uptake experiments may have been at a different stage of the moult cycle than the others in the comparison.

It is interesting to note that, in a parallel study, Boisson et al. (1998) investigated the biology of $\mathrm{Ag}$ and $\mathrm{Hg}$ in the bivalve Macoma balthica subjected to chronic contamination by these metals in the Loire estuary, and concluded that reduced rates of bioaccumulation of silver and mercury are not the mechanism of protection against metal toxicity used by those bivalves surviving laboratory exposure at LT50 concentrations. Nevertheless Bryan \& Hummerstone (1973b) did show that Zn-tolerant Nereis diversicolor from Restronguet
Creek accumulated less Zn than non-tolerant worms from the Avon estuary, although Cu-tolerant $N$. diversicolor from the former site absorbed $\mathrm{Cu}$ more rapidly in the same comparison (Bryan 1974, 1976). In addition Bryan \& Gibbs (1983) concluded that Zn-tolerant crabs Carcinus maenas from Restronguet Creek were generally less permeable to $\mathrm{Zn}$ than non-tolerant conspecifics from the Tamar estuary. Perhaps longer term accumulation studies, including comparisons of excretion rates, may help to resolve this paradox.

Given that the first hypothesis has been rejected, it follows that there is no basis to the second hypothesis proposed - that the mean metal uptake rates of amphipods from the more metal-rich sites will show a greater percentage reduction from control uptake rates. It is still, however, possible to address the third hypothesis - that the mean uptake rates of the amphipods from the metal-rich sites will show smaller CVs than the mean uptake rates of crabs from these same locations. In fact this did not prove to be the case. This cannot be surprising. If there is insufficient selection pressure in the metal-rich sites to drive down a metal uptake rate, then there will probably be insufficient pressure to effect a reduction in the variation in the range of uptake rates.

The lack of an observed effect of raised trace metal availabilities on the metal uptake rates of the resident crustaceans considered here does not eliminate the possibility that other physiological detoxification processes have been affected by any selection pressures present. It is probably the case that suites of physiological mechanisms are present in invertebrates to ameliorate the potential toxic effects of toxic metals (Mason \& Jenkins 1995), and several will interact together in response to a toxic challenge. Thus further studies are needed to investigate the role of intracellular metal detoxification processes (e.g. relative involvement of metal-containing granules, metallothioneins) in the adaptation of coastal invertebrates to chronic exposure to raised availabilities of toxic metals.

Acknowledgements. We are very grateful for support for travel from the Central Research Fund of the University of London, and from the Alliance: Franco-British Joint Research Programme scheme of the British Council and APAPE (France) (Alliance Project PN 97.076)

\section{LITERATURE CITED}

Bartlett BE, Ashcroft CR (1985) Heavy metals in Fucus vesiculosus in the Humber Estuary. Environ Pollut B 9:193-213

Berthet B, Amiard-Triquet C, Martoja R (1990) Effets chimiques et histologiques de la décontamination de l'huitre Crassostrea gigas Thunberg préalablement exposée à l'argent. Water Air Soil Pollut 50:349-363

Bjerregaard P (1982) Accumulation of cadmium and selenium 
and their mutual interaction in the shore crab Carcinus maenas (L.). Aquat Toxicol 2:113-125

Boisson F, Hartl MG, Fowler SW, Amiard-Triquet C (1998) Influence of chronic exposure to silver and mercury in the field on the bioaccumulation potential of the bivalve Macoma balthica. Mar Environ Res 45:325-340

Boult S, Collins DN, White KN, Curtis CD (1994) Metal transport in a stream polluted by acid mine drainage - the Afon Goch, Anglesey, UK. Environ Pollut 84:279-284

Bryan GW (1974) Adaptation of an estuarine polychaete to sediments containing high concentrations of heavy metals. In: Vernberg FJ, Vernberg WB (eds) Pollution and physiology of marine organisms. Academic Press, New York, p 123-135

Bryan GW (1976) Some aspects of heavy metal tolerance in aquatic organisms. In: Lockwood APM (ed) Effects of pollutants on aquatic organisms. Cambridge University Press, Cambridge, p 7-34

Bryan GW, Gibbs PE (1983) Heavy metals in the Fal Estuary, Cornwall: a study of long-term contamination by mining waste and its effects on estuarine organisms. Occ Publ Mar Biol Assoc UK 2:1-112

Bryan GW, Hummerstone LG (1971) Adaptation of the polychaete Nereis diversicolor to estuarine sediments containing high concentrations of heavy metals. I. General observations and adaptation to copper. J Mar Biol Assoc UK 51: $845-863$

Bryan GW, Hummerstone LG (1973a) Brown seaweed as an indicator of heavy metals in estuaries in south-west England. J Mar Biol Assoc UK 53:705-720

Bryan GW, Hummerstone LG (1973b) Adaptation of the polychaete Nereis diversicolor to estuarine sediments containing high concentrations of zinc and cadmium. J Mar Biol Assoc UK 53:839-857

Bryan GW. Langston WJ, Hummerstone, Burt GR (1985) A guide to the assessment of heavy metal contamination in estuaries using biological indicators. Occ Publ Mar Biol Assoc UK 4:1-92

Bryan GW, Gibbs PE, Hummerstone LG, Burt GR (1987) Copper, zinc, and organotin as long-term factors governing the distribution of organisms in the Fal Estuary in Southwest England. Estuaries 10:208-219

Chan HM, Rainbow PS (1993a) The accumulation of dissolved zinc by the shore crab Carcinus maenas (L.). Ophelia 38 $13-30$

Chan HM, Rainbow PS (1993b) On the excretion of zinc by the shore crab Carcinus maenas (L.). Ophelia 38:31-45

Chan HM, Bjerregaard P, Rainbow PS, Depledge MH (1992) Uptake of zinc and cadmium by two populations of shore crabs Carcinus maenas at different salinities. Mar Ecol Prog Ser 86:91-97

Dines HG (1969) The metalliferous mining region of SouthWest England. Her Majesty's Stationery Office, London

Foster P (1976) Concentrations and concentration factors of heavy metals in brown algae. Environ Pollut 10:45-53

Foster P, Hunt DTE, Morris AW (1978) Metals in an acid mine stream and estuary. Sci Tot Environ 9:75-86

Fuge R. James KH (1974) Trace metal concentrations in Fucus from the Bristol Channel. Mar Pollut Bull 5:9-12

Grant A, Hateley JG, Jones NV (1989) Mapping the ecological impact of heavy metals in the estuarine polychaete Nereis diversicolor using inherited metal tolerance. Mar Pollut Bull 20:235-238

Hateley JG, Grant A, Jones NV (1989) Heavy metal tolerance in estuarine populations of Nereis diversicolor. In: Ryland JS, Tyler PA (eds) Reproduction, genetics and distributions of marine organisms. Proc 23rd Eur Mar Biol Symp,
Swansea, Wales, 5-9 September 1988. Olsen \& Olsen, Fredensborg, p 379-385

Jennings JR, Rainbow PS (1979) Studies on the uptake of cadmium by the crab Carcinus maenas in the laboratory. I. Accumulation from seawater and a food source. Mar Biol 50:131-139

Klerks PL, Weis JS (1987) Genetic adaptation to heavy metals in aquatic organisms: a review. Environ Pollut 45:173-205

Luoma SN (1977) Detection of trace contaminant effects in aquatic ecosystems. J Fish Res Bd Can 34:436-439

Martin DJ, Rainbow PS (1998) The kinetics of zinc and cadmium in the haemolymph of the shore crab Carcinus maenas (L.). Aquat Toxicol 40:203-231

Martoja R, Ballan-Dufrançais C, Jeantet AY, Gouzerh P, Amiard JC, Amiard-Triquet $C$, Berthet $B, B$ aud JP (1988) Effets chimiques et cytologiques de la contamination expérimentales de l'huitre Crassostrea gigas Thunberg par l'argent administré sous forme dissoute ou par voie alimentaire. Can J Fish Aquat Sci 45:1827-1841

Mason AZ, Jenkins KD (1995) Metal detoxification in aquatic organisms. In: Tessier A, Turner DR (eds) Metal speciation and bioavailability in aquatic systems. John Wiley \& Sons Ltd, Chichester, p 479-608

Métayer C, Amiard-Triquet C, Baud JP (1990) Variations interspécifiques de la bioaccumulation et de la toxicité de l'argent à l'égard de trois mollusques bivalves marins. Water Res 24:995-1001

Millward RN, Grant A (1995) Assessing the impact of copper on nematode communities from a chronically metal-enriched estuary using pollution-induced community tolerance. Mar Pollut Bull 30:701-706

Moore PG, Rainbow PS, Hayes E (1991) The beach-hopper Orchestia gammarellus (Crustacea: Amphipoda) as a biomonitor for copper and zinc: North Sea trials. Sci Tot Environ 106:221-238

Nieboer E, Richardson DHS (1980) The replacement of the nondescript term 'heavy metals' by a biologically and chemically significant classification of metal ions. Environ Pollut 1:3-26

Rainbow PS (1985) Accumulation of $\mathrm{Zn}, \mathrm{Cu}$ and $\mathrm{Cd}$ by crabs and barnacles. Estuar Coast Shelf Sci 21:669-686

Rainbow PS (1988) The significance of trace metal concentrations in decapods. Symp Zool Soc Lond 59:291-31.3

Rainbow PS (1995a) Physiology, physicochemistry and metal uptake-a crustacean perspective. Mar Pollut Bull 31. $55-59$

Rainbow PS (1995b) Biomonitoring of heavy metal availability in the marine environment. Mar Pollut Bull 31:183-192

Rainbow PS (1997) Ecophysiology of trace metal uptake in crustaceans. Estuar Coast Shelf Sci 44:169-175

Rainbow PS (1998) Phylogeny of trace metal accumulation in crustacears. In: Langston WJ, Bebianno M (eds) Metal metabolism in aquatic environments. Chapman \& Hall. London, p 285-319

Rainbow PS, Kwan MKH (1995) Physiological responses and the uptake of cadmium and zinc by the amphipod crustacean Orchestia gammarellus. Mar Ecol Prog Ser 127: $87-102$

Rainbow PS, White SL (1989) Comparative strategies of heavy metal accumulation by crustaceans: zinc, copper and cadmium in a decapod, an amphipod and a barnacle. Hydrobiologia 174:245-262

Rainbow PS, Moore PG, Watson D (1989) Talitrid amphipods as biomonitors for copper and zinc. Estuar Coast Shelf Sci 28:567-582

Rainbow PS, Malik I, O'Brien P (1993) Physicochemical and physiological effects on the uptake of dissolved zinc and 
cadmium by the amphipod crustacean Orchestia gammarellus. Aquat Toxicol 25:15-30

RNO [Resan National d'Observation] (1995) Les contaminants dans la matière vivante. In: Anonymous (ed) Surveillance du milieu marin. Min Environ, Paris, and IFREMER, Nantes, p $9-24$

Sokal RR, Rohlf FJ (1981) Biometry: the principles and practice of statistics in biological research. WH Freeman, San Francisco

Weeks JM (1992) Copper-rich granules in the ventral caeca of talitrid amphipods (Crustacea: Amphipoda: Talitridae). Ophelia 36:119-133

Editorial responsibility: Scott Fowler (Contributing Editor), Monaco
Weeks JM, Rainbow PS (1990) A dual-labelling technique to measure the relative assimilation efficiencies of invertebrates taking up trace metals from food. Funct Ecol 4: $711-717$

Weeks JM, Rainbow PS (1991) The uptake and accumulation of zinc and copper from solution by two species of talitrid amphipods (Crustacea). J Mar Biol Assoc UK 71: 811-826

Weeks JM, Rainbow PS (1994) Interspecific comparisons of zinc and cadmium relative assimilation efficiencies in an ecological series of talitrid amphipods. Oecologia 97: $228-235$

Submitted: September 16, 1998; Accepted: March 5, 1999 Proofs received from author(s): June 14, 1999 